\title{
Adrenal Cortical Function in Asthmatic Children on Alternate Day Steroids
}

\author{
JAN A. KUZEMKO and JOHN G. LINES \\ From the Paediatric Department, Peterborough District Hospital, Peterborough; and Biochemical Section, \\ John Bonnett Clinical Laboratories, Addenbrooke's Hospital, Cambridge
}

\begin{abstract}
Kuzemko, J. A., and Lines, J. G. (1971). Archives of Disease in Childhood, 46, 366. Adrenal cortical function in asthmatic children on alternate-day steroids. Adrenal cortical function was determined in 16 children receiving prednisolone or prednisolone stearoylglycolate on alternate days. The dosages of the corticosteroids varied from 2.5 to $10 \mathrm{mg}$ prednisolone, or 6.65 to $13.30 \mathrm{mg}$ of its stearoylglycolate ester; the duration of therapy ranged from 2 to 26 months. Adrenocortical function was assessed from the plasma cortisol response to a single injection of $\beta^{1-24}$ tetracosactrin (Synacthen); repeat tests were performed after altering steroid dosages or for reassessment of individual patients.

The effects of prednisolone stearoylglycolate are compared with those of prednisolone, and the effects of alternate-day prednisolone therapy are compared with those found when this corticosteroid was given daily to similar (in three cases, the same) children.
\end{abstract}

The depression of adrenal cortical function by exogenous steroid therapy has been recognized in adults for many years (Shuster and Williams, 1961; Treadwell et al., 1963), and more recently adrenocortical suppression has been demonstrated in children receiving prednisolone in doses as low as $5 \mathrm{mg}$ daily (Kuzemko and Lines, 1970). There have been suggestions that, as the therapeutic action of the steroid persists for more than one day, intermittent rather than daily administration of the corticosteroid might reduce the side effects of the hormonal treatment without affecting the degree of therapeutic action, and of the various regimens tried the administration of the steroid as a single dose once every 48 hours appeared to be the most efficacious (Harter, Reddy, and Thorn, 1963). This alternate day regimen has since been found to be beneficial with a number of steroid preparations, for example, prednisone in the treatment of renal disease in adults (Ackerman and Nolan, 1968) and in children (Soyka, 1967), and has been reported effective with betamethasone in controlling asthma in children (Siegel et al., 1965).

The object of the present work was to investigate whether suppression of adrenal function occurred to the same extent in asthmatic children receiving

Received 28 January 1971. prednisolone once every 48 hours, as was found in our earlier studies (Kuzemko and Lines, 1970) on similar children treated daily with this steroid. Indeed, 4 of the children reported here had been investigated earlier and were changed from a daily to an alternate-day regimen. Adrenocortical function was assessed by the $\beta^{1-24}$ tetracosactrin (Synacthen) test. In three children, including one changed from a daily to alternate-day schedule, the therapeutic steroid was prednisolone stearoylglycolate instead of prednisolone.

\section{Subjects and Methods}

Sixteen children with moderately severe asthma were studied on up to three separate occasions. The minimum period on alternate-day steroids was 2 months, the maximum 26 months. Prednisolone and prednisolone stearoylglycolate dosages varied between $2.5 \mathrm{mg}$ and $10 \mathrm{mg}$ prednisolone or $6.65 \mathrm{mg}$ and $13.3 \mathrm{mg}$ prednisolone stearoylglycolate administered as a single dose every 48 hours $(6.65 \mathrm{mg}$ prednisolone stearoylglycolate is equivalent to $3.5 \mathrm{mg}$ of prednisolone-manufacturer's data). Tetracosactrin tests and the method of cortisol measurement were performed as previously described (Kuzemko and Lines, 1970). The tests were done on the day when the child was not taking any corticosteroids or having tetracosactrin depot injection. In 8 children repeat tests were performed in accord with our previous suggestion (Kuzemko and Lines, 
1970) when the period of treatment was lengthy or after the dosage of corticosteroid had been altered.

\section{Results}

The results of the plasma cortisol analyses before and after $\beta^{1-24}$ tetracosactrin are given in
Tables I, II, and III. The response to tetracosactrin was classified as being normal, abnormal, or as a partial response according to the criteria previously advocated (Kuzemko and Lines, 1970).

The findings show that there is a direct correlation between the dose of corticosteroid and depres-

TABLE I

Children on 2.5 mg Prednisolone or $6.65 \mathrm{mg}$ Stearoylglycolate on Alternate Days

\begin{tabular}{|c|c|c|c|c|c|c|c|c|c|c|}
\hline \multirow{2}{*}{$\begin{array}{l}\text { Case } \\
\text { No. }\end{array}$} & \multirow{2}{*}{$\begin{array}{l}\text { Age } \\
(\mathbf{y r})\end{array}$} & \multirow{2}{*}{ Sex } & \multicolumn{2}{|c|}{$\begin{array}{c}\text { Duration of Therapy } \\
\text { (mth) }\end{array}$} & \multicolumn{3}{|c|}{$\begin{array}{l}\text { Tetracosactrin Test: } \\
\text { Plasma Cortisol Levels } \\
(\mu \mathrm{g} / 100 \mathrm{ml})\end{array}$} & \multirow{2}{*}{ Result* } & \multirow{2}{*}{ Clinical State } & \multirow{2}{*}{$\begin{array}{l}\text { Bronchial } \\
\text { Lability } \\
\text { Index } \\
\text { (Jones, } \\
\text { 1966) }\end{array}$} \\
\hline & & & $\begin{array}{l}\text { Predni- } \\
\text { solone }\end{array}$ & $\begin{array}{l}\text { Prednisolone } \\
\text { Stearoylglycolate }\end{array}$ & Base & $\begin{array}{c}30 \\
\min \end{array}$ & $\begin{array}{l}\text { Incre- } \\
\text { ment }\end{array}$ & & & \\
\hline 1 & $122 / 12$ & $\mathbf{M}$ & 3 & - & $5 \cdot 9$ & $21 \cdot 3$ & $15 \cdot 4$ & $\mathbf{N}$ & $\begin{array}{l}\text { Well; takes disodium cromo- } \\
\text { glycate daily; steroids now } \\
\text { withdrawn }\end{array}$ & II \\
\hline $\begin{array}{l}2 \\
3\end{array}$ & $118 / 12$ & $\begin{array}{l}\mathbf{M} \\
\mathbf{M}\end{array}$ & $\underline{2}$ & $\overline{5}$ & $\begin{array}{l}12 \cdot 5 \\
10 \cdot 0\end{array}$ & $\begin{array}{l}24 \cdot 0 \\
18 \cdot 0\end{array}$ & $\begin{array}{r}11 \cdot 5 \\
8 \cdot 0\end{array}$ & $\begin{array}{l}\mathbf{N} \\
\mathbf{N}\end{array}$ & $\begin{array}{l}\text { Well } \\
\text { Well }\end{array}$ & $\begin{array}{l}\text { II } \\
\text { Tooyoung }\end{array}$ \\
\hline 4 & $82 / 12$ & $\mathbf{F}$ & $\frac{-}{-}$ & $\begin{array}{r}5 \\
14 \\
26\end{array}$ & $\begin{array}{l}\text { (a) } 20 \cdot 0 \\
\text { (b) } 23 \cdot 0 \\
\text { (c) } 9 \cdot 0\end{array}$ & $\begin{array}{l}42 \cdot 2 \\
34 \cdot 5 \\
35 \cdot 0\end{array}$ & $\begin{array}{l}22 \cdot 2 \\
11 \cdot 5 \\
26 \cdot 0\end{array}$ & $\begin{array}{l}\mathbf{N} \\
\mathbf{N} \\
\mathbf{N}\end{array}$ & $\begin{array}{l}\text { Well; takes disodium cromo- } \\
\text { glycate; occasional broncho- } \\
\text { dilator; steroids now with- } \\
\text { drawn }\end{array}$ & II \\
\hline 5 & $77 / 12$ & $\mathbf{M}$ & 19 & 一 & $5 \cdot 0$ & $25 \cdot 0$ & $20 \cdot 0$ & $\mathbf{N}$ & $\begin{array}{l}\text { Well; needs disodium cromo- } \\
\text { glycate; steroids now with- } \\
\text { drawn }\end{array}$ & III \\
\hline
\end{tabular}

* Normal (N); there were no abnormal or partial responses. For details of classification see Kuzemko and Lines (1970).

\section{TABLE II}

Children on 5 mg Prednisolone on Alternate Days

\begin{tabular}{|c|c|c|c|c|c|c|c|c|c|c|}
\hline \multirow{2}{*}{$\begin{array}{l}\text { Case } \\
\text { No. }\end{array}$} & \multirow{2}{*}{$\begin{array}{l}\text { Age } \\
(\mathbf{y r})\end{array}$} & \multirow{2}{*}{ Sex } & \multirow{2}{*}{$\begin{array}{c}\text { Duration } \\
\text { of } \\
\text { Therapy } \\
\text { (mth) }\end{array} \mid$} & \multicolumn{3}{|c|}{$\begin{array}{l}\text { Tetracosactrin Test: } \\
\text { Plasma Cortisol Levels } \\
(\mu \mathrm{g} / 100 \mathrm{ml})\end{array}$} & \multirow{2}{*}{ Result* } & \multirow{2}{*}{ Clinical State } & \multirow{2}{*}{$\begin{array}{l}\text { Bronchial } \\
\text { Lability } \\
\text { Index } \\
\text { (Jones) }\end{array}$} & \multirow{2}{*}{$\begin{array}{l}\text { Studied } \\
\text { on } \\
\text { Daily } \\
\text { Steroidst }\end{array}$} \\
\hline & & & & Base & $\begin{array}{l}30 \\
\mathrm{~min}\end{array}$ & $\begin{array}{c}\text { Incre- } \\
\text { ment }\end{array}$ & & & & \\
\hline 1 & $711 / 12$ & $\mathbf{F}$ & $\begin{array}{l}6 \\
9\end{array}$ & $\begin{array}{l}\text { (a) } 5 \cdot 0 \\
\text { (b) } 9.0\end{array}$ & $\begin{array}{l}25 \cdot 0 \\
29 \cdot 0\end{array}$ & $\begin{array}{l}20 \cdot 0 \\
20 \cdot 0\end{array}$ & $\begin{array}{l}\mathbf{N} \\
\mathbf{N}\end{array}$ & $\begin{array}{l}\text { Well; needs occasional bronchodila- } \\
\text { tors and disodium cromoglycate } \\
\text { daily }\end{array}$ & III & $\begin{array}{l}\text { Case } 5 \\
\text { Table II }\end{array}$ \\
\hline 2 & $53 / 12$ & $\mathbf{M}$ & 3 & $8 \cdot 6$ & $29 \cdot 9$ & $21 \cdot 3$ & $\mathbf{N}$ & $\begin{array}{l}\text { Needs bronchodilators; daily diso- } \\
\text { dium cromoglycate; generally } \\
\text { satisfactory }\end{array}$ & $\begin{array}{l}\text { Too } \\
\text { young to } \\
\text { assess }\end{array}$ & No \\
\hline 3 & $135 / 12$ & $\mathbf{M}$ & $\begin{array}{r}4 \\
12\end{array}$ & $\begin{array}{l}\text { (a) } 15 \cdot 0 \\
\text { (b) } 25 \cdot 5\end{array}$ & $\begin{array}{l}31 \cdot 0 \\
41 \cdot 8\end{array}$ & $\begin{array}{l}16 \cdot 0 \\
16 \cdot 3\end{array}$ & $\begin{array}{l}\mathbf{N} \\
\mathbf{N}\end{array}$ & $\begin{array}{l}\text { Now generally good progress; needs } \\
\text { frequent bronchodilators and di- } \\
\text { sodium cromoglycate ( ?not useful); } \\
\text { occasional antibiotics; treated } \\
\text { Hodgkin's disease }\end{array}$ & III & $\begin{array}{l}\text { Case } 8 \\
\text { Table II }\end{array}$ \\
\hline 4 & $89 / 12$ & $\mathbf{F}$ & 5 & $10 \cdot 9$ & $21 \cdot 8$ & 10.9 & $\mathbf{N}$ & $\begin{array}{l}\text { Well controlled; also on disodium } \\
\text { cromoglycate, steroid dose now } \\
\text { reduced }\end{array}$ & II & No \\
\hline 5 & $74 / 12$ & $\mathbf{F}$ & 4 & $4 \cdot 2$ & $47 \cdot 2$ & $43 \cdot 0$ & $\mathbf{N}$ & Well, steroids now withdrawn & $\begin{array}{l}\text { Too } \\
\text { young to } \\
\text { assess }\end{array}$ & No \\
\hline 6 & $107 / 12$ & $\mathbf{M}$ & 5 & $3 \cdot 0$ & $36 \cdot 0$ & $33 \cdot 0$ & $\mathbf{N}$ & $\begin{array}{l}\text { Needs tetracosactrin depot twice } \\
\text { weekly, bronchodilators and di- } \\
\text { sodium cromoglycate ( ?not effec- } \\
\text { tive); any attempt at withdrawal of } \\
\text { tetracosactrin followed by relapses } \\
\text { of symptoms }\end{array}$ & III & No \\
\hline
\end{tabular}

$\star$ Normal $(\mathrm{N})$; there were no abnormal or partial responses.

+ See Kuzemko and Lines (1970). 
Children on 7·5-10 mg Prednisolone, or 13.3 mg Prednisolone Stearoylglycol

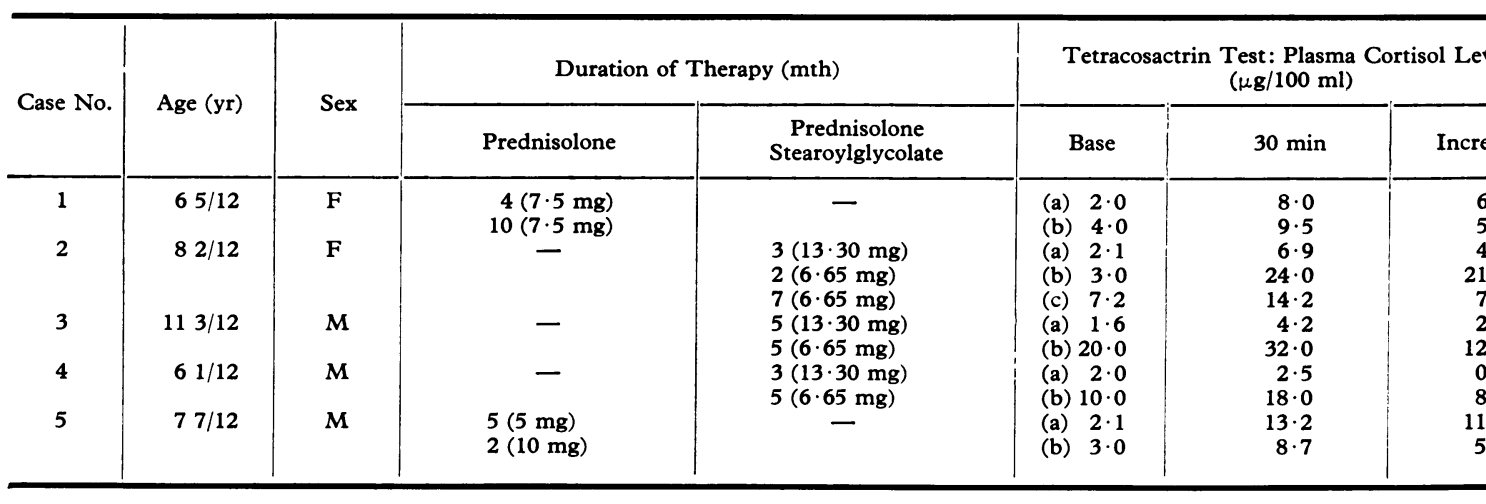

$\star$ Normal (N); Partial response (PR); Abnormal response (A).

† See Kuzemko and Lines (1970).

sion of adrenal cortical activity. All the children on $2.5 \mathrm{mg}$ or $5 \mathrm{mg}$ prednisolone or $6.65 \mathrm{mg}$ prednisolone stearoylglycolate on alternate days had normal adrenocortical reserves. The child who was receiving $7.5 \mathrm{mg}$ prednisolone once every 48 hours produced only a partial response to tetracosactrin on two separate occasions, and one patient (Case 5, Table III) who required an increase in steroid dose from 5 to $10 \mathrm{mg}$ prednisolone showed associated decreased adrenocortical competence. All 3 children given $13.3 \mathrm{mg}$ prednisolone stearoylglycolate on alternate days had frankly abnormal adrenocortical function, but on halving the steroid dosage, there was complete recovery of the adrenal cortex. Case 6 (Table II) and Case 5 (Table III) were given tetracosactrin depot, $125 \mu \mathrm{g}$ twice weekly, but in the latter child who was on $10 \mathrm{mg}$ prednisolone every 48 hours, this did not prevent adrenal suppression.

Of the 4 children who had been on a daily steroid regimen before institution of their alternate day therapy, 3 showed improved adrenocortical function with the latter treatment. In 1 of these 3 (Case 1, Table II), however, though a normal tetracosactrin test result had been obtained after 5 months on $5 \mathrm{mg}$ prednisolone daily, on reduction of the steroid to $5 \mathrm{mg}$ prednisolone once every 48 hours, the incremental response to tetracosactrin after 6 months of this treatment was exactly double that which it had been previously ( $20 \mu \mathrm{g}$ cortisol/ $100 \mathrm{ml}$ plasma compared to $10 \mu \mathrm{g} / 100 \mathrm{ml}$ ). In the two other instances of improvement, the response to tetracosactrin had changed from a frankly abnormal to a normal response (Case 3, Table II) at the $5 \mathrm{mg}$ prednisolone dose, and from an abnormal to a partial reponse on the $10 \mathrm{mg}$ prednisolone regimen (Case 5, Table III), though in this latter case there was an intervening period of 5 months during which the steroid therapy had been $5 \mathrm{mg}$ prednisolone once every 48 hours. It is not possible to compare the daily and alternate day regimens of the fourth child as he was changed from prednisolone daily to the stearoylglycolate ester on alternate days.

\section{Discussion}

This study has shown that adrenocortical suppression may occur when children are given $7.5 \mathrm{mg}$ prednisolone or $13.3 \mathrm{mg}$ prednisolone stearoylglycolate on alternate days. A dose of $5 \mathrm{mg}$ prednisolone or less every 48 hours for up to 12 months did not produce any functional deterioration at the adrenal cortex. This contrasts with the results obtained earlier (Kuzemko and Lines, 1970) in which of 10 similar children receiving $5 \mathrm{mg}$ prednisolone daily, 3 developed some adrenocortical suppression and a further 2 had virtually complete suppression of adrenocortical function after 4 and 9 months, respectively, of this treatment. Of the 6 children who had $10 \mathrm{mg}$ prednisolone daily, all were unable to respond to tetracosactrin; in none of these cases was the incremental response to tetracosactrin as large as that obtained in the one patient given $10 \mathrm{mg}$ prednisolone on alternate days.

These results suggest that alternate day steroid therapy does not produce such deleterious effects upon the adrenal cortex as a daily regimen at the same dose level. No difficulties were found in changing children from daily to alternate day dosages. Control of symptoms was satisfactory with both courses of treatment, and relapses of symptoms were not more frequent in children on 


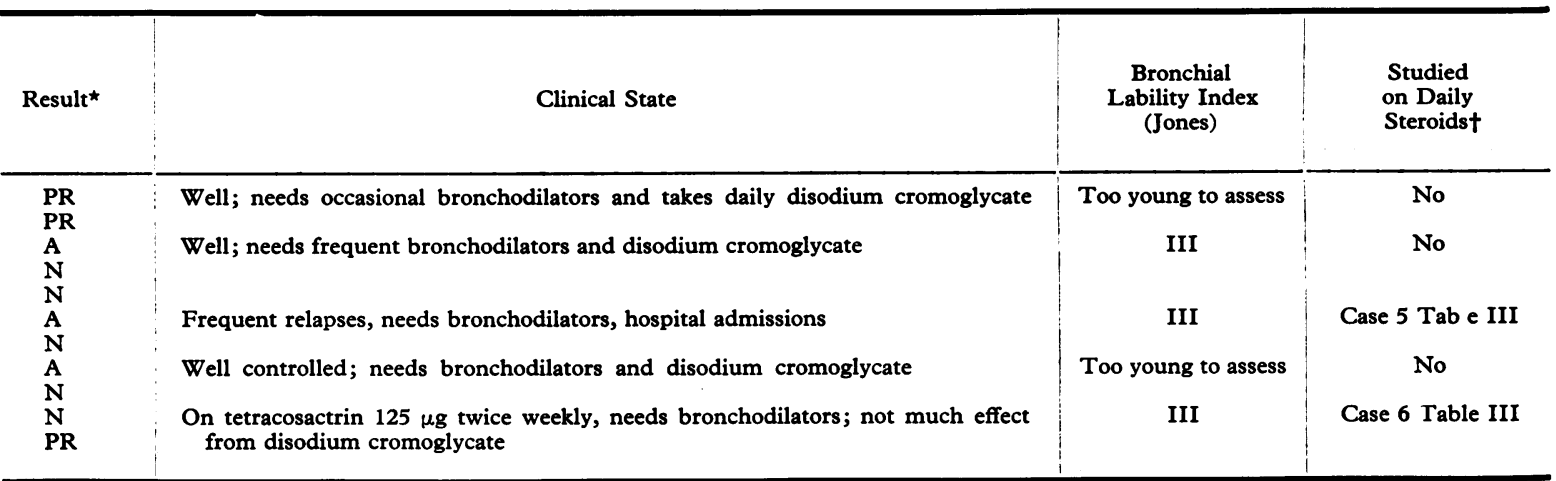

alternate day doses. The risks of withdrawal of corticosteroids in children on single 48-hour treatments appeared to be the same as in children on daily dosages. In 4 children, 3 on $2.5 \mathrm{mg}$ and 1 on $5 \mathrm{mg}$ on alternate days, gradual withdrawal was uneventful and all the children have remained well 6 months later, but we have noted definite psychoneurotic changes in 2 children (Case 5, Table I and in a child on $2.5 \mathrm{mg}$ prednisolone daily), lasting 8 and 10 weeks, respectively, after complete withdrawal of steroids, so that school work was adversely affected. During alternate day therapy, behavioural ('mood') changes have not been observed in children on the days when they did not take any corticosteroids such as have been described in adults who took large doses of corticosteroids (Harter, Reddy, and Thorn, 1963).

Children requiring chronic steroid therapy appear to benefit therefore by maintenance on an alternate day instead of a daily regimen. The same is probably true in many situations for adults. Earlier reports had indicated that a similar conclusion was also applicable where corticosteroid dose levels were much higher both in children (Soyka and Saxena, 1965; Soyka, 1967) and in adults (Ackerman and Nolan, 1968). Whether in children growth rates are also better on alternate day as compared to daily steroid therapy, is not yet certain, but this forms the subject of a continuing study (S. Bedford and J. A. Kuzemko, unpublished data). In this context, though, it is important to distinguish between responses in children and adults, as there is some evidence that a relation exists between steroid dosage and the release of growth hormone (Christie, 1970).

ACTH or any other similar synthetic products do not appear to protect the adrenal cortex suppression when used in combination with prednisolone. Preliminary studies also suggest that in children, ACTH in combination with a corticosteroid causes as much, if not more, stunting of growth as if the child has been on corticosteroids alone (J. A. Kuzemko, unpublished data), and it certainly does not protect them from adrenal suppression when the dose of $7 \mathrm{mg}$ prednisolone is exceededgiven either daily or intermittently. It is likely, therefore, that more harm is done by using both drugs so that it would be better to change to one or the other, preferably ACTH alone since it appears to have a protective function on the hypothalmic-pituitary-adrenal axis (Carter and James, 1970; James, 1970). We have found no advantages in using prednisolone stearoylglycolate in preference to prednisolone. Two patients were worse on the ester and were satisfactorily changed to prednisolone and all 3 patients on prednisolone stearoylglycolate had abnormal tetracosactrin test results when the dose was $13.30 \mathrm{mg}$ (equivalent to $7 \mathrm{mg}$ prednisolone), suggesting greater adrenocortical suppression by the ester on a dose-for-dose basis.

Even using alternate day steroid therapy at low dose levels, it is clear that there is some possibility of adrenocortical suppression. Regular monitoring of the adrenal-hypothalmic-pituitary system must therefore be carried out. The insulin hypoglycaemia test which attempts to assess the efficacy of the complete axis does not correlate well with adrenal cortical function tests (James, 1970; Jasani et al., 1968), and there are some conflicting findings with the lysine-vasopressin test (Brostoff, James, and Landon, 1968). This is probably because the insulin hypoglycaemia test is 'unphysio- 
logical' and endeavours to correlate too many variables. While not minimizing the value of other tests in elucidating any potential disorder of the adrenal-hypothalmic-pituitary axis, the first investigation should be the $\beta^{1-24}$ tetracosactrin test.

This test appears to be the most sensitive index of adrenal cortical reserve in the child, and we fully endorse the comment, which though made about adults is equally applicable to children, that 'subnormal response to $\beta^{1-24}$ tetracosactrin requires corticosteroid “cover" during operations' (Jasani et al., 1968); and would add other stressful situations like infections or accidents when the patient may equally well die from hypotensive shock. Finally, an abnormal tetracosactrin test in an asthmatic child calls for a reassessment of corticosteroid therapy, e.g. reduction of the dosage, accelerated withdrawal with ACTH cover and eventual change to ACTH alone, increase of dosage during periods of stress, and use of additional non-steroid drugs. We have shown that this can be achieved, and thus sudden and unexpected deaths avoided.

We are grateful to our colleagues, Professor H. Lehmann and Dr. B. W. Powell, for their interest and helpful comments.

Correspondence to Dr. J. G. Lines, Biochemical Section, The John Bonnett Clinical Laboratories, Addenbrooke's Hospital, Cambridge CB2 1QE.
REFERENCES

Ackerman, G. L., and Nolan, C. N. (1968). Adrenocortical responsiveness after alternate-day corticosteroid therapy. New England fournal of Medicine, 278, 405.

Brostoff, J., James, V. H. T., and Landon, J. (1968). Plasma corticosteroid and growth hormone response to lysinevasopressin in man. Fournal of Clinical Endocrinology and Metabolism, 28, 511.

Carter, M. E., and James, V. H. T. (1970). Effect of corticotrophin therapy on pituitary-adrenal function. Annals of Rheumatic Diseases, 29, 73.

Christie, C. (1970). Growth studies and steroids. Steroid Symposium, Cambridge. Unpublished.

Harter, J. G., Reddy, W. J., and Thorn, G. W. (1963). Studies on an intermittent corticosteroid dosage regimen. New England Fournal of Medicine, 269, 591.

James, V. H. T. (1970). The investigation of pituitary-adrenal function: effects of corticosteroids and corticotrophin therapy. Pharmacologica Clinica, 2, 182.

Jasani, M. K., Freeman, P. A., Boyle, J. A., Reid, A. M., Diver, M. J., and Buchanan, W. W. (1968). Studies of the rise in plasma 11-hydroxycorticosteroids (11-OHCS) in corticosteroidtreated patients with rheumatoid arthritis during surgery: correlations with the functional integrity of the hypothalmopituitary-adrenal axis. Quarterly fournal of Medicine, 37, 407.

Jones, R. S. (1966). Assessment of respiratory function in the asthmatic child. British Medical fournal, 2, 972.

Kuzemko, J. A., and Lines, J. G. (1970). Adrenal cortical function in children on steroids. Archives of Disease in Childhood, $45,215$.

Shuster, S., and Williams, I. A. (1961). Pituitary and adrenal function during administration of small doses of corticosteroids. Lancet, 2, 674.

Siegel, S. C., Heimlich, E. M., Richards, W., Taylor, W. F., and Kelley, V. C. (1965). Effects of alternate-day steroid therapy in asthmatic children. Fournal of Allergy, 36, 209.

Soyka, L. F. (1967). Treatment of the nephrotic syndrome in childhood: use of an alternate-day prednisone regimen. American fournal of Diseases of Children, 113, 693.

Soyka, L. F., and Saxena, K. M. (1965). Alternate-day steroid therapy for nephrotic children. Fournal of the American Medical Association, 192, 225.

Treadwell, B. L. J., Savage, O., Sever, E. D., and Copeman, W. S. C. (1963). Pituitary-adrenal function during corticosteroid therapy. Lancet, 1, 355. 